\title{
Promising Breeding Material from Triticum Turgidum L.
}

\section{Boris Romanov, Konstantin Pimonov, and Irina Sorokina}

Federal State Budget Educational Institution of Higher Education «Don State Agrarian University», Per-sianovsky, Rostov region, Russia

ORCID:

Konstantin Pimonov: http://orcid.org/0000-0003-0726-2583

\section{Abstract}

Turgid wheat is distinguished by a large multi-grain ear. Therefore, the involvement of its varieties in the selection process to increase the productivity of winter durum wheat is very promising. This paper shows the results of creating a highly productive source material to improve the production capabilities of existing varieties of winter hard and turgid wheat. To do this, a cross was performed between a loose-leaved multi-grain variety var.martensii with a large-seeded and dense-leaved var.salomonis. By weight of the grain from the ear, the resulting hybrids significantly exceeded the original parent

Corresponding Author: Konstantin Pimonov konst.pimonov@yandex.ru

Published: 5 April 2021

Publishing services provided by Knowledge E

(c) Boris Romanov et al. This article is distributed under the terms of the Creative Commons Attribution License, which permits unrestricted use and redistribution provided that the original author and source are credited.

Selection and Peer-review under the responsibility of the DonAgro Conference Committee.

\section{G OPEN ACCESS} forms and the zoned varieties of winter hard and turgid wheat, cultivated simultaneously with them, but they were taller. When a hybrid was crossed with a modern low-growing variety of Terra, more productive forms were produced relative to the zoned varieties and the same short-stem forms, which can be used as a promising source of breeding material. The selected hybrids, both individually and on average, clearly outperformed the zoned varieties of durum and turgid wheat in terms of grain weight per ear. The production characteristics of the ear on average for the hybrid were as follows: the length of the ear was $7.6 \mathrm{~cm}$, and 18.9 spikelets and 57.5 grains were formed.

Keywords: Triticum turgidum, varieties, hybrid forms, productivity, source material, zoned varieties

\section{Introduction}

Currently, much attention is paid to the genetic diversity of wheat, up to the creation of synthetic forms of it [1]. However, turgid wheat (Triticum turgidum L.) also has a number of useful features for breeding and, first of all, high productivity. Many varieties of T. turgidum have a large, multi-grain ear, which can be used to create more productive varieties. The indicators of high production of turgid wheat, compared to other types, are currently confirmed by relevant studies that have been carried out on the basis of the collection of wheat species of the FRANTZ FGBNU $[2,3]$. Therefore, to increase the 
production capacity of modern varieties of winter hard and turgid wheat, it is desirable to involve representatives of the latter in the selection process as much as possible.

Turgid wheat includes winter, semi-winter and spring forms. The overwhelming advantage belongs to the first [4]. Since the technological characteristics of T. turgidum L. are very close to that of durum wheat (Triticum durum desf.) on the basis of some of its varieties, winter varieties were and are created, which, as representatives of durum wheat, are mainly used for the production of pasta. Accordingly, in regions where winter crops are more productive, the use of plump wheat instead of less productive varieties of durum wheat is used in spring, will give a certain advantage in increasing the gross production of such raw materials. At the same time, by simultaneously cultivating winter turgid wheat and spring hard wheat, it is possible, without significantly affecting the quality of raw materials, to provide processors with a stable volume of grain for a more rhythmic and systematic operation of macaroni enterprises. In addition, it should be borne in mind that spring wheat is less productive than winter wheat and is most demanding to growing conditions, and, first of all, to soil moisture availability $[5,6]$. Therefore, the production of so-called winter varieties of durum wheat is being launched in a huge amount [7].

It should be noted that many specialists, not to mention producers, do not make special distinctions between hard and turgid wheat, although, as indicated above, they differ significantly in their production characteristics.

The goal of this work is to demonstrate the prospects for using different varieties of turgid wheat to create highly productive selection and perspective forms that can be used to improve the production indicators of modern varieties of winter hard and turgid wheat.

\section{Methods and Equipment}

Very contrasting varieties of turgid wheat were used as the starting material for obtaining highly productive genotypes: var.martensii - loose - leaved, var.salomonis-denseleaved. It should be noted that T. turgidum var. salomonis belongs to the group with a very large grain - gigantosemineum [2]. When hybridizing these samples, we expected a successful recombination of the features of the parent forms in the hybrid offspring, which happened. The resulting hybrids are involved in hybridization with modern production varieties of winter hard and turgid wheat, which were regularly cultivated in the same experiments. 
To assess the production characteristics in the phase of full ripeness, $15-25$ productive shoots of each sample were selected and, after drying, a structural analysis was performed. Mathematical processing was performed using standard Microsoft Excel computing programs.

\section{Results and Discussion}

To create highly productive genotypes of turgid wheat as a parent plant, a loose-leafed form with a large number of grains was used, and it was pollinated with pollen from a dense-leafed form with a large grain (Figure 1). Here are the ears of the fourth generation of hybrid plants. These are well-established genotypes. It should be noted that the parent forms are quite tall and, accordingly, the hybrids also turned out to be relatively tall, which had a bad effect on their resistance to lodging.

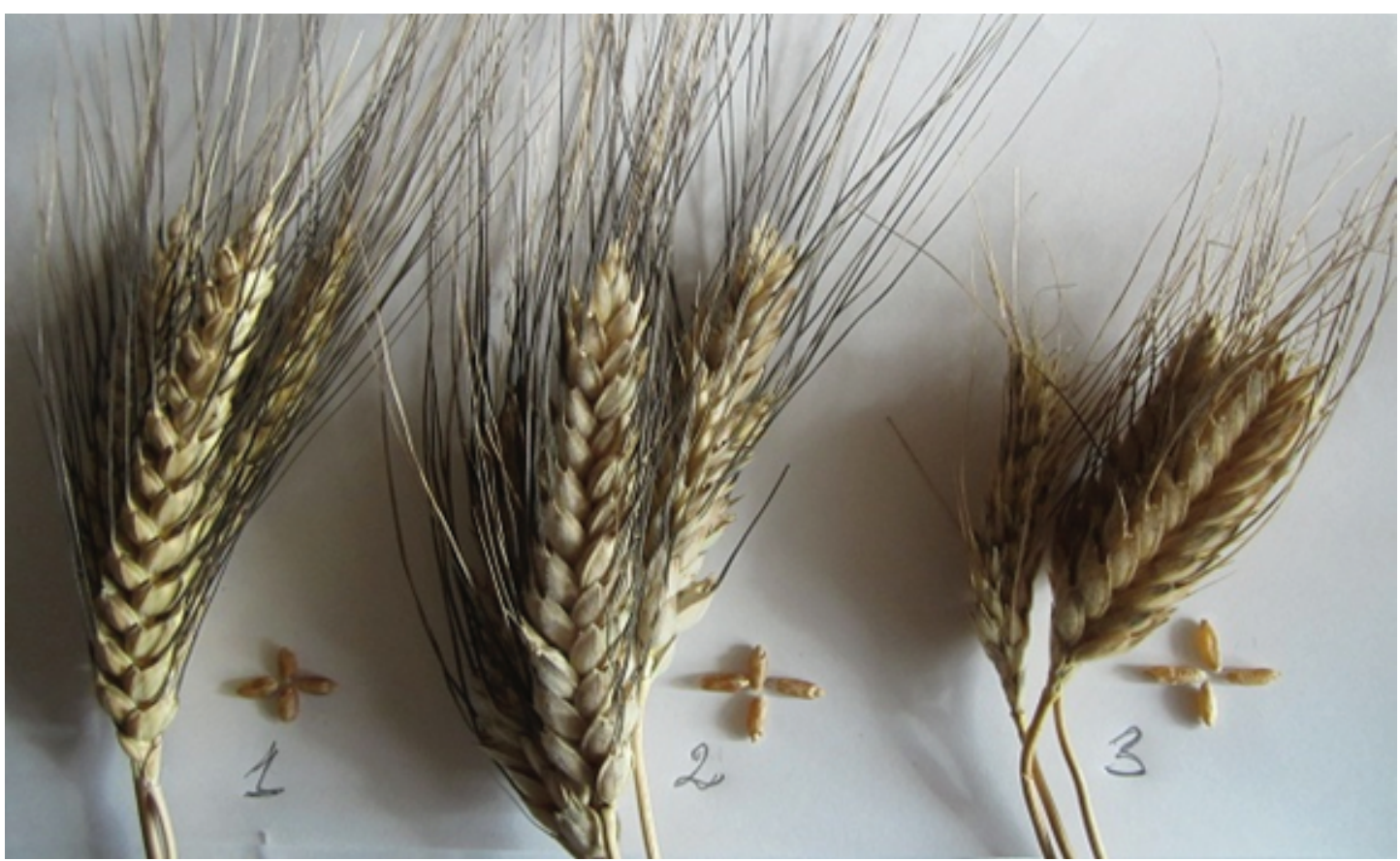

Figure 1: Ears: 1 - original loose-leaf, 2 - hybrid F4, 3 - dense-leaved form of turgid wheat.

Table 1 shows the production characteristics of the original forms and the F4 hybrid. Hybrid plants occupy an intermediate position along the length of the ear. In hybrid forms, it is $8.6 \mathrm{~cm}$. This is $2.1 \mathrm{~cm}$ longer than the original tightly offset shape and $1.7 \mathrm{~cm}$ shorter than the loosely offset shape.

In terms of the number of spikelets and grains from the ear, the hybrid exceeds the parent forms of wheat, although the differences are not reliable in the latter indicator. 
TABLE 1: Production characteristics of ears of initial forms and hybrid F4 turgid wheat

\begin{tabular}{|l|c|c|c|c|}
\hline Genotypes & $\begin{array}{c}\text { Length of the ear, } \\
\text { cm }\end{array}$ & \multicolumn{2}{|c|}{$\begin{array}{c}\text { Number of pieces } \\
\text { spikelet }\end{array}$} & $\begin{array}{c}\text { Weight of grains, } \\
\mathrm{g}\end{array}$ \\
\hline loose-headed & 10.3 & 18.4 & 51.0 & 2.78 \\
\hline thick-headed & 6.5 & 19.4 & 49.6 & 2.60 \\
\hline hybrid & 8.6 & 21.7 & 58.1 & 3.80 \\
\hline LSD $_{05}$ & 1.1 & 2.0 & 10.1 & 0.82 \\
\hline
\end{tabular}

It is very important that the weight of the grain from the ear, the selected hybrid plants significantly exceed the original parent forms.

Later, in the comparative analysis, along with the studied forms, a zoned, but relatively low-growing variety of turgid wheat Terra was included (Table 2). As can be seen from the height of the plants, the hybrid is also an intermediate inheritance, compared to the original forms $(95.3 \mathrm{~cm})$; however, this is significantly higher than the plants of the zoned variety Terra $(66.9 \mathrm{~cm})$. In addition to low growth, it is significantly behind in the area of the flag leaf, the number of spikelets and the weight of grain per ear from the hybrid. However, since Terra is well-established in production and, most importantly, a short-stemmed variety, the next step is to cross the resulting hybrid with it.

TABLE 2: Characteristics of morphostructural features of initial forms, hybrid F5 and zoned variety of turgid wheat Terra

\begin{tabular}{l|c|c|c|c|c|c|}
\hline Genotypes & Height, $\mathrm{cm}$ & $\begin{array}{c}\text { S flag Sheet, } \\
\mathrm{cm}^{2}\end{array}$ & $\begin{array}{c}\text { Length of the } \\
\text { Ear, } \mathrm{cm}\end{array}$ & \multicolumn{2}{|c|}{$\begin{array}{c}\text { Number of pieces } \\
\text { spikelet }\end{array}$} & $\begin{array}{c}\text { Weight of } \\
\text { grains, } \mathrm{g}\end{array}$ \\
\hline $\begin{array}{l}\text { loose- } \\
\text { headed }\end{array}$ & 112.1 & 21.2 & 10.2 & 24.4 & 40.2 & 2.38 \\
\hline $\begin{array}{l}\text { thick- headed } \\
\text { hybrid }\end{array}$ & 87.8 & 22.3 & 7.3 & 22.0 & 33.8 & 2.08 \\
\hline LSD & 95.3 & 23.1 & 8.7 & 23.3 & 52.0 & 3.38 \\
\hline Genotypes & 66.9 & 15.1 & 7.4 & 16.2 & 51.2 & 2.00 \\
\hline
\end{tabular}

In the second generation, genotypes comparable in height to Terra (50 - 75cm) were selected (Table 3). Then, 5 genotypes selected from this combination were compared with zoned varieties of winter hard and turgid wheat cultivated in the same experiment (Table 4).

All the selected hybrids, individually and on average, clearly exceeded the weight of grain from the ear of the zoned varieties (Table 4). From the data in Table 3, hybrids under No. 2 and No. 5 show the highest indicators, although the rest are quite convincingly superior to the zoned varieties and, accordingly, is of considerable interest as a source material for further hybridization to increase the production capacity 
TABLE 3: Production characteristics of ears of selected hybrid short-stemmed forms of turgid wheat from the combination (tur $\times$ tur) $\times$ Terra of 2019

\begin{tabular}{|l|c|c|c|c|}
\hline Genotype & $\begin{array}{c}\text { Length of the ear, } \\
\text { cm }\end{array}$ & \multicolumn{2}{|c|}{ Number of pieces } & $\begin{array}{c}\text { Weight of grains, } \\
\text { g }\end{array}$ \\
\hline Hybrid No. 1 & & spikelet & grains \\
\hline Hybrid No. 2 & 8.6 & 17.6 & 56.2 & 2.30 \\
\hline Hybrid No. 3 & 7.5 & 20.7 & 68.3 & 3.23 \\
\hline Hybrid No. 4 & 7.4 & 18.6 & 47.6 & 2.44 \\
\hline Hybrid No. 5 & 7.2 & 18.3 & 59.7 & 2.64 \\
\hline Average for the hybrid & 7.9 & 20.0 & 76.0 & 3.03 \\
\hline
\end{tabular}

of existing varieties. All zoned varieties that were used in the same experiment were inferior to the resulting hybrids (Table 4). Therefore, the hybrid forms of turgid wheat selected from this combination, especially under No. 2 and No. 5, are very promising breeding material. In this regard, we present the data produced during hybridization of the hybrid (tur $x$ tur) $x$ Terra with the Donchanka variety (Table 5). As one can see, hybrid forms have been produced more productive than the original winter durum wheat Donchanka. Work with these hybrid forms continues.

TABLE 4: Production characteristics of winter ears zoned varieties of turgid and durum wheat, 2019

\begin{tabular}{|c|c|c|c|c|}
\hline \multirow[t]{2}{*}{ Genotype } & \multirow{2}{*}{$\begin{array}{l}\text { Length of the ear, } \\
\qquad \mathrm{cm}\end{array}$} & \multicolumn{2}{|c|}{ Number of pieces } & \multirow{2}{*}{$\begin{array}{l}\text { Weight of grains, } \\
\text { g }\end{array}$} \\
\hline & & spikelet & grains & \\
\hline Don amber & 6.6 & 19.6 & 49.7 & 1.76 \\
\hline Pearl of the Don & 6.9 & 21.8 & 48.3 & 1.82 \\
\hline Courant & 6.9 & 18.8 & 54.5 & 1.90 \\
\hline Kristella & 7.2 & 17.0 & 49.8 & 2.00 \\
\hline Antaria & 6.8 & 20.5 & 43.2 & 1.75 \\
\hline Donchanka & 6.5 & 21.1 & 48.8 & 1.98 \\
\hline Average for the variety & 6.8 & 19.8 & 49.1 & 1.87 \\
\hline
\end{tabular}

TABLE 5: Characteristics of the original form of Donchanka and hybrid $\mathbf{F}_{2}\{$ Donchanka $x$ [(tur $x$ tur)x Terra]

Genotype
Original form of
Donchanka
$\mathbf{F}_{2}$ \{Donchanka x [(tur x
tur)x Terra $]\}$
LSD $_{05}$

\begin{tabular}{|c|}
$\begin{array}{c}\text { Height of } \\
\text { plants, } \mathrm{cm}\end{array}$ \\
\hline 65.0 \\
\hline 68.0 \\
\hline 4.9
\end{tabular}

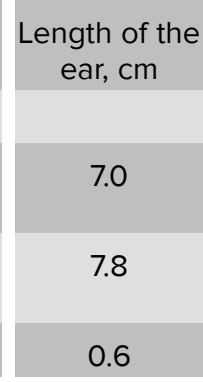

\begin{tabular}{|c|}
\hline Number \\
\hline spikelet \\
\hline 21.6 \\
\hline 21.0 \\
\hline 2.2 \\
\hline
\end{tabular}

\begin{tabular}{|c|}
\hline of pieces \\
\hline grains \\
\hline 53.1 \\
\hline 62.8 \\
\hline 13.1 \\
\hline
\end{tabular}

$\begin{gathered}\text { Weight of } \\ \text { grains, } g\end{gathered}$
2.18
2.97
0.63




\section{Conclusion}

When crossing sharply contrasting varieties of T. turgidum, relatively tall hybrid forms with high productivity of ears are produced. During further hybridization of the resulting tall genotype with the short-stemmed zoned Terra variety, relatively low-growing forms were produced, which are very promising breeding material for increasing the productivity of existing varieties of winter hard and turgid wheat.

\section{Acknowledgement}

The authors would like to thank their colleague for their contribution and support of the research. They are also thankful to all the reviewers who gave their valuable inputs to the manuscript and helped in completing the paper.

\section{Conflict of Interest}

The authors have no conflict of interest to declare.

\section{References}

[1] Khakimova, A. G., et al. (2019). Genetic Diversity and Breeding Value of Synthetic Hexaploid Wheat Attracted to the VIR Collection. Vavilov Journal of Genetics and Plant Breeding, vol. 23, issue 6, pp. 738-745.

[2] Romanov, B. V. (2006). On the Question of the Hexa-And Octoploid Level of Quantitative Traits in Naked Tetraploid Wheat Species. Agricultural Biology, No. 3, pp. 101-108.

[3] Romanov, B. V. and Pimonov, K. I. (2018). Phenomogenomics of Production Signs of the Species of Wheat. Rostov-on-Don, Persianovsky, p. 188.

[4] Dorofeev, V. F., et al. (1987). Wheat of the World. Leningrad: VO "Agropromizdat", p. 559.

[5] Zelenskaya, G. M., Polyakov, V. V. and Esekova, A. A. (2019). Spring Wheat at Various Growing Technologies. Presented at Proceedings of the International Scientific Conference, February 7, Rostov-on-Don, Persianovsky, pp. 108-110.

[6] Titarenko, A. V. and Korobova, N. A. (2013). Ecological Variety Testing of Grain and Leguminous Crops in the Conditions of the Azov Zone of the Rostov Region. Grain Economy of Russia, vol. 3, issue 27, pp. 41-45. 
[7] Samofalova, N. E., et al. (2012). Hard (Turgid) Winter Wheat in the Rostov Region (Varietal Composition, Cultivation Technology, Seed Production). Rostov-on-Don: CJSC “Kniga”, p. 80. 